\title{
Monetary Policy in Jobless Recoveries
}

\author{
Michael R. Pakko
}

$\mathrm{T}$ he relatively slow pace of economic growth during the current recovery-particularly the sluggish performance of labor markets-has inspired numerous comparisons to the "jobless" recovery that followed the 1990-91 recession. While there are some striking similarities between the two episodes, each recession is unique and one should not carry comparisons too far. Nevertheless, it is interesting to consider similarities and differences in the responses of monetary policy during the two recoveries.

Based on the official dating by the National Bureau of Economic Research, both the 1990-91 and 2001 recessions lasted for eight months. Both recessions were relatively mild compared with previous economic downturns, and both were followed by recoveries that did not display the typical rapid bounce-back in growth and employment. Following the business cycle trough of March 1991, cumulative growth in private nonfarm payroll employment remained negative for 18 months. Similarly, cumulative employment growth during the 21 months since the November 2001 turning point has also been negative.

By at least one measure, the stance of monetary policy during these recession/recovery periods has been similar as well. The chart shows a measure of the "real" federal funds rate- the spread between the federal funds rate target established by the Federal Open Market Committee (FOMC) and the inflation rate, measured here as the previous 12-month change in the core personal consumption expenditures (PCE) deflator. This measure shows that the FOMC progressively eased policy during both recessions. In the periods following these recessions, the real federal funds rate ultimately declined to below zero and remained near zero for several months.

The chart also shows an important difference in the real funds rate behavior: During the most recent recession, the FOMC lowered the federal funds rate target more rapidly than it did in the previous recession. Between July 1990 and March 1991 the funds rate target was reduced eight times for a cumulative total of 225 basis points. A series of further small rate cuts lowered the funds rate an additional 2 percentage points by the end of 1991, bringing the real federal funds rate down to zero. Three more rate cuts followed in 1992, which maintained a real funds rate near zero as inflation declined.
During the more recent recession, the FOMC also reduced the funds rate target eight times, but in larger increments. Rate cuts in March through November 2001 reduced the target by 350 basis points, bringing the real funds rate close to zero by the trough of the recession. Additional rate cuts in December 2001, November 2002, and June 2003 reduced the funds rate another percentage point.

The timing and magnitude of policy changes during these two episodes are significant because monetary policy is thought to affect the economy with a lag. Ultimately, the sluggish recovery of the early 1990s gave way to the rapid expansion later in the decade, but it wasn't until February 1994nearly three years after the trough of the recession-that the expansion had picked up noticeable momentum and the FOMC began raising the funds rate target. Despite the lackluster performance of job growth, the recovery from the 2001 recession has already begun showing signs of picking up momentum. Many factors contribute to ongoing macroeconomic developments, but the Fed's relatively rapid and forceful response to deteriorating economic conditions during the 2001 recession is one factor that might help make this jobless recovery shorter than the previous episode.

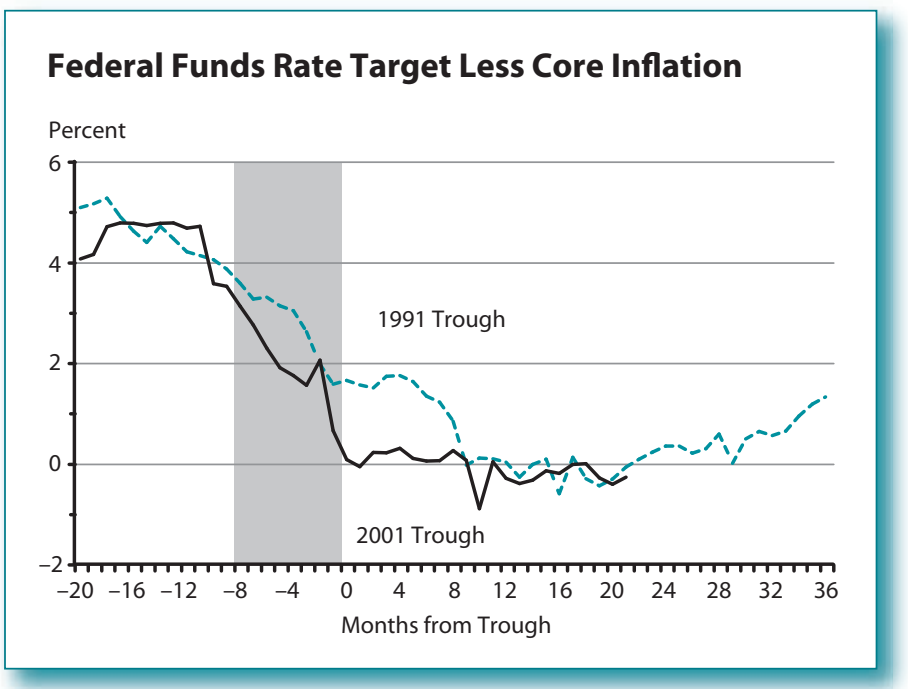

